\title{
May Business Mentors Act as Opportunity Brokers and Enablers Among University Students? To What Extent? ${ }^{1}$
}

Étienne St-Jean ${ }^{2}$, Ph.D., Professor, Research Institute on SMEs, University of Québec at Trois-Rivières, 3351, boul. des Forges, Trois-Rivières (Québec), Canada, G9A 5H7. Email: etienne.st-jean@uqtr.ca, Tel: 1-819-376-5011 \#4293.

Maripier Tremblay, DBA, Professor at Université Laval, Faculté des sciences de l'administration, Pavillon Palasis-Prince, local 1523, Québec (Québec), G1V 0A6. Email: Maripier.Tremblay@,fsa.ulaval.ca, Tel: 1-418-656-2131, \# 4961.

Frank Janssen, Ph.D., Professor at la Louvain School of Management, Université Catholique de Louvain, Place des Doyens, 1, 1348 Louvain-La-Neuve, Belgium. Email: frank.janssen@uclouvain.be, Tel.: +32 (0)10 478428.

Jacques Baronet, Ph.D., Professor at Université de Sherbrooke, 2500, boul. de l'Université Sherbrooke (Québec) Canada, J1K 2R1. Jacques.Baronet@USherbrooke.ca, Tel.: 1-819-8218000, \# 63050. Email:

Christophe Loué, Ph.D., Professor-researcher at NOVANCIA, 3 rue Armand Moisant, Paris (France) 15 ${ }^{\mathrm{ème}}$, Email: cloue@novancia.fr, Tel.: 06.63.60.46.18.

Aziz Nafa, Economist-researcher at the Centre de Recherche en Économie Appliquée pour le Développement (CREAD), division Firmes et Économie Industrielle, BP 187 - Rostomia Bouzaréah - Alger - Algeria. Email: aziznafa@gmail.com, Tel.: +213 021941272.

\begin{abstract}
Networks are recognized as a central component of the entrepreneurial process, in particular with regard to opportunity identification and exploitation. In this study, we more specifically analyze the role of mentors who are in business as opportunity brokers and enablers among university students with entrepreneurial intentions. Our investigation with 1022 students from 13 French-language universities in Canada, France, Belgium and Algeria indicates that mentors in business, contrary to other mentors, support opportunity identification and exploitation among university students. Although student gender, entrepreneurial experience and education have a more pronounced effect, mentoring is the only element that can be controlled through the creation of formal support programs. These results call on public authorities, and universities in particular, to implement formal mentoring programs to support students who are interested in starting their own business, and who would not otherwise have access to business mentors in their environment.
\end{abstract}

Keywords: Mentoring, Opportunity identification, Opportunity exploitation, University students

\footnotetext{
${ }^{1}$ St-Jean, E. et al., (2017), “ May Business Mentors Act as Oppurtunity Brokers and Enablers Among University Students? To What Extent? ", International Entrepreneuship and Management Journal, Vol. 13, pp. 97-111. https://doi.org/10.1007/s11365-016-0397-4

${ }^{2}$ Corresponding author.
} 


\section{Introduction}

The concept of business opportunity is at the heart of entrepreneurship (Shane and Venkataraman 2000). The notion of opportunity relates an enterprising individual, one who intends to be his/her own boss, to unfulfilled (or insufficiently fulfilled) needs that enable the creation of a new business (Eckhardt and Shane 2003; Shane 2003). Several factors have been identified as important for opportunity recognition. Notably, the entrepreneur's knowledge (Shane 2000; Shepherd and DeTienne 2005), cognitive schemes (Baron and Ensley 2006), psychological predispositions, such as alertness to opportunities (Shepherd and DeTienne 2001; Ko and Butler 2007), social capital and networking (Dubini and Aldrich 1991; Singh 2000; Puhakka 2006; Gordon 2007).

Recently, it has been suggested (ex. Barès et al. 2004) and demonstrated that mentors are capable of helping novice entrepreneurs identify business opportunities (Gordon 2007; Ozgen and Baron 2007; St-Jean and Audet 2012). What about individuals who are likely to start a business but have not yet started? Despite de fact that mentors can help foster entrepreneurship and enhance the entrepreneur's competencies through learning, it appears that no research has focused on mentoring and its impact on the entrepreneurial process leading to the start-up. To our knowledge, only Fuentes Fuentes et al. (2010) assert that potential entrepreneurs are more likely to set up business initiatives if they maintain frequent and close relationships with other businesspeople, or if they receive support from entrepreneurial associations. This assertion has recently been demonstrated by Radu-Lefebvre and Redien-Collot (2013). They show that mentors in business can influence the business start-up and help support fundraising activities. However, their sample consists of 50 students enrolled in a business school in France that is dedicated to entrepreneurship. This can bias the outcome of their study.

Our research aims to verify whether business mentors working with university students can help them identify and exploit business opportunities. Given that mentoring helps established entrepreneurs to identify opportunities, as previously mentioned this research will contribute in defining the benefits of this practice in the upstream part of the entrepreneurial process. If mentors were to act as knowledge brokers, by helping potential entrepreneurs obtain new information to identify better opportunities, this would improve the success rate of novice entrepreneurs. Therefore, suggesting a more in-depth investigation regarding how new knowledge circulates within the entrepreneurial ecosystem, as well as knowing the main actors (beyond mentors) who play a significant role, and how this could support the emergence of new business in a region.

Furthermore, this research will contribute to a better understanding of the role of business mentors as opportunity enablers. Gaining knowledge could expedite the exploitation phase of entrepreneurs (Choi et al. 2008). Since mentors can provide knowledge to nascent entrepreneurs, we aim to demonstrate that mentors can foster opportunity exploitation among potential entrepreneurs, especially university students.

From a practical standpoint, such a contribution will confirm the effect of mentoring on potential business creators and, in particular, university students. A strong positive effect would suggest pairing mentors with university students who wish to start their own business once their studies completed. On the one hand, it would foster business creation by identifying promising opportunities, and on the other hand, by reducing the fear of investing time and resources on these opportunities.

First, a literature review on the concept of business opportunities and thei determining factors are presented, followed by a discussion on mentoring and its potential effects on the process of identifying and exploiting an opportunity. Then, the methodology, followed by the results of the analyses conducted among a large sample of university students from four 
countries. And finally, the results are discussed and practical implications for public authorities are highlighted.

\section{Literature review}

Over the last few years, several groups of researchers have focused on the entrepreneurial intentions of individuals. A recent meta-analysis retrieved 98 studies where the dependent variable is entrepreneurial intent (Schlaegel and Koenig 2014). However, studies on entrepreneurial intention share an important weakness regarding the relationship between entrepreneurial intention and the actual start-ups. Theoretically, the intention to start a business, which is planned behaviour, is the closes indicator of the behaviour (i.e. start-up) and should be a direct correlation between entrepreneurial intentions and business creation. To our knowledge, only Katz (1990) shows that among all the people who have the intention to start a business, only $18 \%$ will take action within a four-year timeframe.

The situation could simply be explained by a lack of business opportunities, where the individual is unable to translate intention into action. Indeed, business creation is based on the identification and exploitation of a business opportunity perceived by an individual operation in a given business environment (Shane and Venkataraman 2000; Shane 2003). Since it is through opportunity that entrepreneurial intention can be translated into action, which leads to business creation, this study focuses on the ability of university students to identify and exploit opportunities. Such indicators could be of greater use, since they are more concrete and rooted in action, and would therefore enable us to relate intention to creation. Opportunity exploitation is in fact closely related to the creation process, which is of greater interest, both practically and theoretically, than entrepreneurial intentions.

\section{Mentors as opportunity brokers}

Information and knowledge appear to be important dimensions of the opportunity recognition process (Franzoni 2007). Generally speaking; knowledge influences the nature, number and level of innovativeness of the opportunities that are identified (Kaish and Gilad 1991; Shane 2000; Sheperd and DeTienne 2001; Davidsson and Honig 2003; Dimov 2003; Orwa 2003; Sheperd and DeTienne 2005; Vaghely and Julien 2010). Given the importance of the use of information to identify opportunities, some authors have shown that networks, which help to circulate information, could also have a positive impact on opportunity identification (Singh et al. 1999; De Carolis and Saparito 2006; Puhakka 2006; Chabaud and Ngijol 2010). Those studies highlight the fact that entrepreneurs need social interaction to acquire knowledge. Social interactions enable entrepreneurs to determine relevant information and help develop a better understanding of future needs, which in turn helps them to identify opportunities.

Beyond the importance of the use of information to recognize opportunities, Gaglio (2004) stresses the key role of heuristics in the cognitive process of entrepreneurs engaged in an opportunity identification phase. In the same vein, Baron and Ensley (2006) shiw that over the years experienced entrepreneurs develop patterns that enable them to identify opportunities more easily and in larger numbers (Ucbasaran et al. 2009) Thus, it is not only the information itselfthat is important in the opportunity recognition process, but how it is processed by human cognition as well.

One of the main benefits of a mentoring relationship in various contexts is the learning outcomes that result from discussions with the mentor (Wanberg et al. 2003). This is alose the case with entrepreneurial mentoring relationships (Sullivan 2000), where affective and cognitive learnings outcomes prevail (Deakins et al. 1998; Cull 2006; Gravells 2006; Sarri 
and Petridou 2006; St-Jean 2012; St-Jean and Audet 2012; Radu Lefebvre and Redien0Collot 2013). Mentors help generate new options for the entrepreneur's business (Gravells 2006). Entrepreneurs who restrict themselves to knowledge, based on their own experience, end up with a limited ability to recognize opportunities, but could go beyond this threshold through discussion with a mentor (Ucbasaran et al. 2009). As observed, a mentor can give tacit information to the novice entrepreneur, allowing the latter to reach beyond his/her lack of experience and identify opportunities (Smith et al. 2009). If the positive effects of mentors have been shown on novice entrepreneurs, it is reasonable to assume that such a relationship would have a similarly positive effect on potential business creators. As such, mentors from the business world can provide relevant information about markets, technology, production process, management, and so forth, to students who are working on their business opportunity. As shown by Baron and Ensley (2006), experienced entrepreneurs develop cognitive schemes differently that novices. This enables them to think about new products, or services, that are more specific and morel likely to generate sales. In other contexts, for example education, mentoring is proposed as a means for novices to develop expert cognitive schema (Livingston and Borko 2989; Westerman 1991; Stanulis and Jeffers 1995; OrlandBarak and Yinon 2005). Thus, an experiences mentor could enhance a novice's cognitive scheme that is less effective in identifying opportunities. In sum, by providing access to information and knowledge, and by helping to analyse information from different angles, a mentor is likely to increase the ability of new venture creators to recognize opportunities and, thus, to act as an opportunity broker. These considerations lead to the following hypothesis:

$\mathrm{H} 1$ : Business mentors act as opportunity brokers and positively influence opportunity identification among potential entrepreneurs.

\section{Mentors as opportunity enablers}

Fuentes Fuentes et al. (2010) demonstrate that the strength of social network ties has positive effects on opportunity exploitation. They assert that entrepreneurs are more likely to set up business initiatives if frequent and close relationships are maintained with other businesspeople, or if supported by entrepreneurial associations. Others have shown that the entrepreneurial network facilitates access to financing (Jenssen and Kownig 2002) and more generally, to other types of resources (Hite 2005; Jones and Jayawarna 2010). Entrepreneurs can also use networks to learn and to improve their capacity to exploit business opportunities, especially when a high level of trust exists between its members (Bergh et al. 2011). By providing the potential entrepreneur with business contacts and occasions to learn (Cope 2003; Cope and Watts 2000; St-Jean 2011), the mentor can alose act as an "opportunity enabler" by facilitating access to resources that are needed to exploit the identified opportunity (Grossman et al. 2012).

Mentors with an extensive experience in the business world could also enable university students to test their business idea on the market and turn it into an opportunity. With their mentor's approval, students could develop greater confidence in their project and could move on more easily to the exploitation phase. Self-efficacy perception is another cognitive variable that influences the opportunity recognition process (Krueger and Dickson 1994; Ozgen 2003). The decision to exploit a business opportunity is always taken in unpredictable contexts where outcomes are uncertain. Thus, individuals with high selfefficiency (and optimism) are more likely to exploit opportunities because this requires them to act amid everybody else's skepticism (Shane and Venkataraman 2000; Ardichvili et al. 2003). Entrepreneurs with high self-efficacy believe that they can succeed in pursuing an opportunity regardless of the environment (Mitchell and Sheperd 2010). They also believe 
that they can persist when committed to a failing course of action (Whyte et al. 1997), highlighting the importance of entrepreneurial action. Just as fear is a negative emotion that prevents the exploitation of opportunities (Welpe et al. 2012), having a strong sense of selfefficacy should trigger the exploitation phase. Self-efficacy beliefs are central in the opportunity exploitation phase. Moreover, self-efficacy perception, regardless of the context, is a well-recognized outcome of the mentoring relationship (Powers et al. 1995; Cull 2006; Hulela and Miller 2006; Rigg and O’Dwyer 2012; Gimmon et al. 2014). In supporting selfefficacy, mentoring could be what allows students to take action once they identify an opportunity. Furthermore, with the support of an experiences businessperson, students may be more inclined to invest the financial resources and times required to translate the project into reality. And, as mentioned above, mentors may suggest ways for the potential entrepreneur to access resources or get in touch with people wo can provide the needed resources. If the mentor doubts the opportunity identified by the student, he/she can then provide advice on how to enhance it feasibility. In other words, having a mentor from the business world could accelerate the opportunity identification phase and help students to move on to the exploitation phase. These observations lead to the following hypothesis:

$\mathrm{H} 2$ : Business mentors act as opportunity enablers and positively influence opportunity exploitation among potential entrepreneurs.

\section{Methodology}

This section describes the sample used to test our hypotheses. A presentation of the measures used for the various concepts and of our analysis methods will follow.

\section{Sample}

The sample used in this study was drawn from a survey on entrepreneurial career. Students from 13 universities were contacted to answer a questionnaire: Ten Canadian universities, one Belgian university, one French school of commerce, and one Algerian university. The invitation was sent by email, posted on student Intranets or institutional journals. A total of 1,810 students agreed to take part in this first phase of the five-year annual investigation. This is, of course, a non-probabilistic sample, given that only the interested students agreed to participate.

Most respondents studied in Canada (64\%), followed by Belgium (18.5\%), France $(9.5 \%)$ and Algeria (8\%). Although they were from different university departments, except for the French students, they were mostly registered in Management Sciences (37.5\%), Pure Sciences and Engineering (25.5\%), Human and Social Sciences (9.9\%) and among other disciplines. They were mostly undergraduate students $(55.4 \%)$ and to a lesser degree, masters $(39.6 \%)$ or doctoral $(5 \%)$ students. The sample mostly included Caucasian students $(84,4 \%)$, followed by students of Arabic (8\%), Black-African (4,1\%) descent and others (3,5\%). In our sample, we kept only the students who in the past had never been entrepreneurs and who did not own a business at the time of our investigation. This brings our final sample to 1540 students. We did this to ensure that no potential bias gets in the way of our analysis, since entrepreneurial experience can enhance the capacity to identify or exploit an opportunity. 


\section{Measures}

\section{Dependant variables - business opportunities}

We provided the participants in this study with the following definition of a business opportunity:

"A business opportunity can be defined as a situation in which new products, services, raw materials or production methods may be successfully introduced and which we believe can be sold for a higher price than the cost of production. In other words, it is the meeting point between current or future client needs and the available resources to meet those needs, all in a timely fashion and in a manner perceived as economically profitable"3.

We then asked them to indicate the number of business opportunities they had identified over the previous five (5) years (opportunity identification) and subsequently, in how many they had invested any effort to exploit them (opportunity exploitation). This method of measuring opportunity identification and exploitation has been suggested and used by several authors in the past (e.g. Ardichvili et al. 2003; Shepherd and DeTienne 2005; Ucbasaran et al. 2008).

The number of business opportunities identified varies from 0 to 10 or more, with a mean of 3.34 (median 3) and a standard deviation of 2.75. The distribution is not normal, and follows a Poisson-type distribution, where the incidence of identifying few opportunities is very high, as opposed to the incidence of finding several opportunities, which is low. In this case, $33.8 \%$ of the respondents identified " 0 " or " 1 " opportunities. We withdrew outliers $(+10$ identified opportunities) from our sample.

The number of exploited opportunities also varies from 0 to 10 or more, with a mean of 1.74 (median 1) and a standard deviation of 1.42. Here again, the distribution is not normal and follows a Poisson-type distribution, where $60.7 \%$ of cases had exploited " 0 " or " 1 " opportunities, whereas $0.5 \%$ had exploited 10 opportunities or more.

\section{Independent variable - mentoring}

We provided the respondents with the following definition of a mentor: "A mentor is defined as a high-ranking individual who is experienced or has expertise and who teaches, advises, inspires, guides and helps another person with their personal and professional development".

We subsequently asked them to identify the number of individuals in their lives who could be considered as mentors (number of mentors) and, from that number, how many of them owned a business (mentors in business). To calculate the number of mentors who are not in business, we subtracted the number of mentors in business from the total number of mentors reported. Seven (7) cases had to be withdrawn, since it resulted in a negative number of mentors not in business, showing a problem of validity with these cases. We created a binary variable for: having a mentor in business $(0=$ Not having a mentor in business, $1=$ Having a mentor in business) and another for having a mentor not in business ( $0=$ Not having a mentor, $1=$ Having a mentor not in business) and used them in the analysis.

\footnotetext{
${ }^{3}$ Our translation.
} 


\section{Control variables}

Literature on opportunity recognition by entrepreneurs indicates that knowledge and information acquired through prior work experience helps improve an individual's ability to identify opportunities (Shane 2000; Shepherd and DeTienne 2005). Tacit knowledge, especially that which is acquired through experience as a manager, can also improve opportunity identification (Ardichvili et al. 2003; Davidsson and Honig 2003), as with the level of education in general (Davidsson and Honig 2003; Arenius and Clercq 2005). Clearly, having an intention to start a business is a necessary, but not sufficient condition to explain the opportunity identification and exploitation process. Self-efficacy in opportunity recognition can also help trigger the process (Krueger and Dickson 1994; Tumasjan and Braun 2012). Having parents who were entrepreneurs themselves, could obviously influence the dependant variables, as well as socio-demographic variables such as gender and age. The capacity to access resources could potentially explain the opportunity-exploitation decision (Choi and Sheperd 2004). Therefore, it was included in our analysis, as well as the other above-mentioned variables.

Concerning the measures of these variables, work experience refers to the number of years of full-time work experience. Supervision experience refers to the number of years of full-time experience as staff manager or supervisor. The capacity to obtain resources results from the answer to the following question: "In your opinion, obtaining funds to sustain the creation of a business would be", with a 7-point Likert scale from 1-Very difficult, to 7-Very easy. Family in business means that one of the respondent's parents had or currently owned a business. Entrepreneurial intention is the extent to which students have the intention to start a business in the future, from 1-Not at all, to 5-Very highly probable. Self-efficacy of opportunity recognition is based on a 4-item measure developed by McGee et al. (2009). Respondents were asked to specify to what extent they perceive themselves capable of efficiently handling different recognition tasks, from $0 \%$ to $100 \%$, with $10 \%$ steps. The Cronbach alpha for this measure is 0,830 .

\section{Analysis}

Since both dependent variables were distributed according to Poisson's law, a Poisson regression analysis was used. This type of regression enables to calculate the probability that a given event will happen (dependent variable), based on a linear function of a set of predictors (independent variables) specified in the test. Students who did not complete the survey were excluded from our analysis, therefore lowering the number of respondents to 1022 .

\section{Results}

Table 1 presents means, standard deviations, and correlations of variables in this study.

As illustrated in Table 2, gender is a significant predictor of opportunity identification and exploitation, with women showing a lower overall rate of identification $(\beta=-0.184)$ and exploitation $(\beta=-0.115)$. Age is significant for neither opportunity identification nor exploitation. Level of education has a low but significant effect on the probabilities of identifying an opportunity $(\beta=0.086)$, but not on the exploiting phase. Work or supervision experience, capacity to obtain resources, or family exposure to entrepreneurship has no impact on opportunity identification and exploitation. However, as expected, entrepreneurial intention strongly and significantly explains the probability of identifying an opportunity $(\beta=$ $0.174)$ and exploiting it $(\beta=0.178)$. Regarding opportunity recognition, self-efficacy has a 
small but significant effect on identification $(\beta=0.064$, Exp $[\beta] 1066)$ but not on exploitation. Lastly, mentors in business positively affect the probability that students will identify $(\beta=$ $0.122)$ and exploit $(\beta=0.151)$ business opportunities, whereas mentors outside the business world will not. These results confirm $\mathrm{H} 1$ and $\mathrm{H} 2$.

Table 1

Mean, standard deviation, and correlations ${ }^{a}$ between variables

\begin{tabular}{lrrrrrrrrrrrr}
\hline & Mean & S.D. & \multicolumn{1}{c}{1} & 2 & 3 & 4 & 5 & 6 & 7 & 8 & 9 & 10 \\
\hline 1-Gender & 0.55 & 0.50 & 1.00 & & & & & & & & & \\
2-Age & 24.20 & 5.03 & .059 & 1.00 & & & & & & & & \\
3-Education & 1.49 & 0.59 & -.008 & .285 & 1.00 & & & & & & & \\
4-Work experience & 2.85 & 2.94 & .071 & .791 & .116 & 1.00 & & & & & & \\
5-Supervision exp. & 1.55 & 1.56 & .019 & .601 & .072 & .627 & 1.00 & & & & & \\
6-Obtain resources & 3.62 & 1.55 & -.094 & .019 & -.089 & .052 & .057 & 1.00 & & & & \\
7-Family business & 0.44 & 0.50 & .036 & -.011 & -.093 & -.006 & .013 & .082 & 1.00 & & & \\
8-Self-efficacy-OR & 6.38 & 2.00 & -.176 & .103 & .031 & .069 & .013 & .149 & .035 & 1.00 & & \\
9-Ent. Intention & 3.03 & 1.37 & -.230 & .103 & .068 & .097 & .101 & .138 & .146 & .421 & 1.00 & \\
10-Mentor not bus. & 0.55 & 0.50 & .038 & -.038 & -.047 & -.001 & .039 & .119 & .390 & .102 & .284 & 1.00 \\
11-Mentor in bus. & 0.71 & 0.45 & .064 & -.008 & .004 & -.005 & -.014 & .024 & -.085 & -.042 & -.126 & -.062 \\
\hline
\end{tabular}

Table 2

Poisson Regression of Opportunity Identification and Exploitation among University Students

\begin{tabular}{|c|c|c|c|c|c|}
\hline & \multicolumn{3}{|c|}{$\begin{array}{l}\text { Opportunity } \\
\text { Identification }\end{array}$} & \multicolumn{2}{|c|}{ Opportunity Exploitation } \\
\hline & B & & $\operatorname{Exp}(\beta)$ & $\beta$ & $\operatorname{Exp}(\beta)$ \\
\hline (Constant) & -0.137 & & 0.872 & -0.248 & 0.781 \\
\hline Gender ${ }^{a}$ & -0.184 & $* * *$ & 0.832 & $-0.115 *$ & 0.891 \\
\hline Age & 0.002 & & 1.002 & 0.009 & 1.009 \\
\hline Education & 0.086 & $*$ & 1.090 & -0.049 & 0.952 \\
\hline Work experience & 0.008 & & 1.008 & 0.001 & 1.001 \\
\hline Supervision experience & 0.024 & & 1.024 & 0.019 & 1.019 \\
\hline Capacity to obtain resources & -0.007 & & 0.993 & -0.013 & 0.987 \\
\hline Family in business ${ }^{b}$ & -0.001 & & 1.001 & -0.056 & 0.945 \\
\hline Self-efficacy - Opportunity & 0.064 & $* * *$ & 1.066 & 0.010 & 1.010 \\
\hline Entrepreneurial intention & 0.174 & $* * *$ & 1.190 & $0.178 * * *$ & 1.195 \\
\hline Mentors outside business ${ }^{c}$ & -0.030 & & 0.970 & -0.014 & 0.986 \\
\hline \multirow[t]{2}{*}{ Mentors in business ${ }^{\circ}$} & 0.104 & $*$ & 1.110 & $0.115 *$ & 1.122 \\
\hline & \multicolumn{3}{|c|}{1022} & \multicolumn{2}{|c|}{1069} \\
\hline
\end{tabular}

\section{Discussion}

The results of this study demonstrate that mentors who are in business have a positive effect on opportunity identification and exploitation among university students, as opposed to mentors who are not in business. This confirms what others have already claimed, such as successful opportunity identification and exploitation depends, in particular, on access to social networks, including mentors (Ardichvili et al. 2003). It has also been shown that social networks influence both the cognitive bias of entrepreneurs and the creation process of new businesses (De Carolis et al. 2009), where the latte can be seen as opportunity exploitation. 
Informal networks also influence the success of a newly created business (Hormiga et al. 2011). However, our results specify that simply networking in general (e.g. Singh 2000; Arenius and Clercq 2005; Gordon 2007) does not necessarily impact opportunity identification and exploitation, since mentors who are not in business had no effect.

Furthermore, our results show that men are more likely to identify and exploit opportunities. This is perfectly consistent with studies which show that men are more likely to intend to start a business and to follow through (De Bruin et al. 2007; Bosma and Levie 2009; Gupta et al. 2009; Díaz-García and Jiménez-Moreno 2010). It thus seems logical to observe that men identify and exploit opportunities more, since they have a higher level of intention to start a business and engage in entrepreneurial careers to a greater extent (Amorós and Bosma 2014). Our results do not confirm the influence of past work experience, which could be a source of opportunity identification and exploitation (Shane 2000; Shepherd and DeTienne 2005). This is probably due to the fact that our sample is composed of university students. Even is some may have relevant experience, they might not have as much experience as a representative sample of the whole population. Contrary to what was expected, having parents who are or were entrepreneurs had no effect on opportunity identification or exploitation. However, parents in business may have been counted among the mentors in business if they matched the previously given definition of a mentor. In certain cases, parents may in fact act as mentors toward their children. Thus, the simple fact of having parents who are entrepreneurs is not enough to increase the probability of identifying or exploiting business opportunities, in particular among university students. As expected, education has an effect on opportunity identification, but not on exploitation. Truly, human capital supports the opportunity recognition process (Ucbasaran et al. 2008; Dimov 2010) and it is observed here, even if the variance be more capable of identifying opportunities than undergraduates. Their level of specialized knowledge could be an important factor to turn their business idea into an opportunity, but not for it to be exploited, it needs to be commercialized. This requires another kind of knowledge (business knowledge) (Ardichvili and Cardozo 2000). Our results demonstrate the accuracy of this argument.

Also, as expected, self-efficacy in opportunity recognition leads to better opportunity identification (Tumasjan and Braun 2012). However, contrary to what we expected, selfefficiency has no impact on opportunity exploitation. This means that the exploitation phase does not require efficacy perception to be enacted. Risk propensities would be more appropriate than self-efficacy to explain the exploitation phase (Krueger and Dickson 1994) and the timing market entry (Choi and Sheperd 2004; Choi et al. 2008).

Moreover, we observed a strong relationship between entrepreneurial intention and opportunity identification and exploitation. Previous research focused on entrepreneurial intention (e.g. Giacomin et al. 2011; Shinnar et al. 2012; St-Jean et al. 2014;) and researchers proposed measures for intention (e.g. Thompson 2009). Based on the strong relationship between intentions, opportunity recognition, the exploitation process, and the fact that identifying an opportunity may be the missing link between intention and action, we suggest using opportunity identification and exploitation measures in future researches. Focusing on opportunity identification and exploitation may reduce the time gap that exists from the time a person thinks about being an entrepreneur, and the moment they start the venture. As very few measures of opportunity identification and exploitation have been developed, researchers suggest to use triangulation (Short et al. 2010). To take the study a step further, respondents could be asked to explain the opportunity identified, in order to independently assess their value (Grégoire et al. 2010), and if times was invested to exploit it. Douglas (2013) suggest to incorporate a predisposition for growth in the entrepreneurial intention to construct. This maybe be another promising path to follow. 
Finally, our results show that being supported by a mentor in business has the secondstrongest effect in explaining opportunity identification and exploitation, after entrepreneurial intention. This could be the missing link between intentions and actual business creation. As a result, implementing mentoring programs could stimulate the business start-ups of university graduates, at a minimal cost. For public authorities, and universities in particular, this stresses the relevance of enhancing entrepreneurial training programs with a mentoring component. This would enable students to operationalize the knowledge acquired in the classroom by providing them with more tangible applications. Even if in other contexts informal mentoring is sometimes observed to be more effective than formal mentoring (Chao et al. 1992; Baugh and Fagenson-Eland 2007), formal programs are important for individuals who cannot easily access mentoring informally (Viator 1999; Baugh and Fagenson-Eland 2007). For students who are less networked and who are not intouch with entrepreneurs, having access to a formal mentoring program could be their stepping stone entrepreneurial culture. It could also be interesting to investigate Entrepreneurs-in-residence programs and their capacity to enhance opportunity identification and exploitation among students (George et al. 2010).

\section{Limitations and future research avenues}

Among the limitations and future research avenues, it should first be noted that this study used perceptual measures. Thus, within this study, opportunity identification and exploitation are subjective rather than objective notions, which gives us only a partial picture. It could be interesting, for example, to measure a novice's ability to identify opportunities with an external resource, such as a banker, business angel, VC, or one who often does that kind of assessment professionally. In addition, the transversal nature of our study is somewhat of a limitation, which should be improved by conduction a longitudinal study as part of our future research for the coming years. We should also mention that our sample is representative of the whole population of students as a whole and has a potential self-selection bias. Even if this situation is more problematic with causation studies, which is not the case in this research, it could potentially affect our analysis.

We now know that mentors in business have a positive effect on opportunity identification and exploitation and can thus act as opportunity brokers and enablers. However, knowing that the learning outcomes that are likely to result from mentoring are about content and processes (Politis 2005), how mentors stimulate opportunity identification and exploitation, through adding information (Ucbasaran et al. 2009) or in transforming cognitive schemes (Baron and Ensley 2006), remains to be demonstrated. These are just a few possible avenues for future research.

\section{Conclusion}

Mentoring is recognized as an effective support for novice entrepreneurs; its cognitive and affective outcomes improve business performance and entrepreneurial career retention (StJean and Audet 2012). Our research show that mentoring is also the relevant upstream of the entrepreneurial process, namely to nascent entrepreneurs. Opportunity is at the heart of the entrepreneurship research and is divided in two sequential steps: identification and exploitation (Corbett 2005). We showed that mentors who are in business are effective for improving opportunity identification, as well as opportunity exploitation. Therefore, mentors act as opportunity brokers and enablers. Since opportunity identification and exploitation lead to business creation, it is consequently important to understand the role of business mentors in order to foster venture creations. 
This study used a sample of university students, and thus brings an important practical implication. After completing their studies, students will be facing a choice. Will they work as salaried employees, or will they invest time and resources in pursuing an entrepreneurial career? Knowing that mentors are effective in opportunity identification and exploitation, it therefore suggests pairing a business mentor with a student who has entrepreneurial intentions in order to foster business creation. Since not everyone has access to informal business mentoring, this also suggests that universities should implement formal mentoring programs for students who are interested in becoming entrepreneurs.

\section{References}

Ajzen, I. (1991). The theory of planned behavior. Organizational Behavior and Human Decision Processes, 50(2), 179-211.

Amorós, J. E., \& Bosma, N. (2014). Global Entrepreneurship monitor - 2013 global report. Santiago: Universidad del Desarrollo .

Ardichvili, A., \& Cardozo, R. N. (2000). A model of the entrepreneurial opportunity recognition process. Journal of Enterprising Culture, 8(2), 103-119.

Ardichvili, A., Cardozo, R. N., \& Ray, S. (2003). A theory of entrepreneurial opportunity identification and development. Journal of business venturing, 18(1), 105-123.

Arenius, P., \& Clercq, D. (2005). A network-based approach on opportunity recognition. Small Business Economics, 24(3), 249-265.

Baron, R. A., \& Ensley, M. D. (2006). Opportunity Recognition as the Detection of Meaningful Patterns: Evidence from Comparisons of Novice and Experienced Entrepreneurs. Management Science, 52(9), 1331-1344.

Baugh, S. G., \& Fagenson-Eland, E. (2007). Formal mentoring programs: A "poor cousin" to informal relationships. In B. R. Ragins, \& K. E. Kram (Eds.), The handbook of mentoring at work: Theory, research, and practice (pp. 249-271). Los Angeles, USA: Sage Publications.

Bergh, P., Thorgren, S., \& Wincent, J. (2011). Entrepreneurs learning together: The importance of building trust for learning and exploiting business opportunities. International Entrepreneurship and Management Journal, 7(1), 17-37.

Bosma, N., \& Levie, J. (2009). Global Entrepreneurship Monitor: 2009 Executive Report.

Chabaud, D., \& Ngijol, J. (2010). Quels réseaux sociaux dans la formation de l'opportunité d'affaires ? Revue française de Gestion, 38(206), 129-147.

Chao, G. T., Walz, P. M., \& Gardner, P. D. (1992). Formal and Informal Mentorships: A Comparison on Mentoring Functions and Contrast With Nonmentored Counterparts. Personnel Psychology, 45(3), 619-636.

Choi, Y. R., \& Sheperd, D. A. (2004). Entrepreneurs' decision to exploit opportunities. Journal of Management, 30(3), 377-395.

Choi, Y. R., Lévesque, M., \& Sheperd, D. A. (2008). When should entrepreneurs expedite or delay opportunity exploitation? Journal of Business Venturing. 23(3), 333-355.

Cope, J. (2003). Entrepreneurial learning and critical reflection: discontinuous events as triggers for 'higher-level' learning. Management Learning. 34(4), 429-450. doi:10.1177/1350507603039067.

Cope, J., \& Watts, G. (2000). Learning by doing-an exploration of experience, critical incidents and reflection in entrepreneurial learning. Internation Journal of Entrepreneurial Behaviour \& Research, 6(3), 104-124. doi: 10.1108/13552550010346208

Corbett, A. C. (2005). Experiential learning within the process of opportunity identification and exploitation. Entrepreneurship: Theory and Practice, 29(4), 473-491. doi:10.1111/j.1540-6520.2005.00094.x. 
Cull, J. (2006). Mentoring young entrepreneurs: what leads to success? International Journal of Evidence Based Coaching and Mentoring, 4(2), 8-18.

Davidsson, P., \& Honig, B. (2003). The role of social and human capital among nascent entrepreneurs. Journal of business venturing, 18(3), 301-331.

De Bruin, A., Brush, C. G., \& Welter, F. (2007). Advancing a framework for coherent research on women's entrepreneurship. Entrepreneurship Theory and Practice, 31(3), 323-339.

De Carolis, D. M., Litzky, B. E., \& Eddleston, K. A. (2009). Why networks enhance the progress of new venture creation: The influence of social capital and cognition. Entrepreneurship Theory and Practice, 33(2), 527-545.

De Carolis, D. M., \& Saparito, P. (2006). Social capital, cognition, and entrepreneurial opportunities: A theoretical framework. Entrepreneurship Theory and Practice, 30(1), 41-56.

Deakins, D., Graham, L., Sullivan, R., \& Whittam, G. (1998). New venture support: an analysis of mentoring support for new and early stage entrepreneurs. Journal of Small Business and Enterprise Development, 5(2), 151-161.

Díaz-García, M. C., \& Jiménez-Moreno, J. (2010). Entrepreneurial intention: the role of gender. International Entrepreneurship and Management Journal, 6(3), 261-283.

Dimov, D. The nexus of individual and opportunity: Opportunity recognition as a learning process. In Frontiers of entrepreneurship research, Babson: MA. Babson College, 2003 (pp. 410-420)

Dimov, D. (2010). Nascent entrepreneurs and venture emergence: opportunity confidence, human capital, and early planning. Journal of Management Studies, 47(6), 1123-1153.

Douglas, E. J. (2013). Reconstructing entrepreneurial intentions to identify predisposition for growth. Journal of Business Venturing, 28(5), 633-651.

Dubini, P., \& Aldrich, H. (1991). Personal and extended networks are central to the entrepreneurial process. Journal of business venturing, 6(5), 305-313.

Eckhardt, J., \& Shane, S. A. (2003). Opportunities and Entrepreneurship. Journal of Management, 29(3), 333-349.

Franzoni, C. (2007). Opportunity recognition in technology transfer organizations. International Entrepreneurship and Management Journal, 3(1), 51-67.

Fuentes Fuentes, M. d. M., Ruiz Arroyo, M., Bojica, A. M., \& Fernández Pérez, V. (2010). Prior knowledge and social networks in the exploitation of entrepreneurial opportunities. International Entrepreneurship and Management Journal, 6(4), 481501.

Gaglio, C. M. (2004). The Role of Mental Simulations and Counterfactual Thinking in the Opportunity Identification Process. Entrepreneurship Theory and Practice, 28(6), 533-552.

George, M., Gordon, I., \& Hamilton, E. (2010). What is (the point of) an entrepreneur in residence? the Lancaster University experience, with some worldwide comparisons. Industry and Higher Education, 24(6), 495-503.

Giacomin, O., Janssen, F., Pruett, M., Shinnar, R. S., Llopis, F., \& Toney, B. (2011). Entrepreneurial intentions, motivations and barriers: differences among American, Asian and European students. International Entrepreneurship and Management Journal, 7(2), 219-238.

Gimmon, E., McCracken, M., \& Matlay, H. (2014). Mentoring as a practical training in higher education of entrepreneurship. Education + Training, 56(8/9).

Gordon, S. R. (2007). Interpersonal trust, vigilance and social networks roles in the process of entrepreneurial opportunity recognition. International Journal of Entrepreneurship and Small Business, 4(5), 564-585. 
Gravells, J. (2006). Mentoring start-up entrepreneurs in the East Midlands - Troubleshooters and Trusted Friends. The International Journal of Mentoring and Coaching, 4(2).

Grégoire, D. A., Shepherd, D. A., \& Lambert, L. S. (2010). Measuring opportunityrecognition beliefs illustrating and validating an experimental approach. Organizational Research Methods, 13(1), 114-145.

Grossman, E. B., Yli-Renko, H., \& Janakiraman, R. (2010). Resource Search, Interpersonal Similarity, and Network Tie Valuation in Nascent Entrepreneurs' Emerging Networks. Journal of Management (Published online first).

Gupta, V., Turban, D., Wasti, S., \& Sikdar, A. (2009). The role of gender stereotypes in perceptions of entrepreneurs and intentions to become an entrepreneur. Entrepreneurship Theory and Practice, 33(2), 397-417.

Hite, J. M. (2005). Evolutionary processes and paths of relationally embedded network ties in emerging entrepreneurial firms. Entrepreneurship Theory and Practice, 29(1), 113144.

Hormiga, E., Batista-Canino, R. M., \& Sánchez-Medina, A. (2011). The Impact of Relational Capital on the Success of New Business Start-Ups. Journal of Small Business Management, 49(4), 617-638.

Hulela, K., \& Miller, W. (2006). Self-efficacy development in a one-to-one mentoring strategy for faculty integrating technology in agricultural education. In C. M. Crawford, R. Carlsen, K. McFerrin, J. Price, R. Weber, \& D. A. Willis (Eds.), Society for information technology \& teacher education international conference 2006 (pp. 3435-3439). Orlando: AACE.

Jenssen, J. I., \& Koenig, H. F. (2002). The Effect of Social Networks on Resource Access and Business Start-ups. European Planning Studies, 10(8), 1039-1046.

Jones, O., \& Jayawarna, D. (2010). Resourcing new businesses: social networks, bootstrapping and firm performance. Venture Capital, 12(2), 127-152.

Kaish, S., \& Gilad, B. (1991). Characteristics of opportunities search of entrepreneurs versus executives: Sources, interests, general alertness. Journal of business venturing, 6(1), 45-61.

Katz, J. A. (1990). Longitudinal analysis of self-employment follow-through. Entrepreneurship \& Regional Development, 2(1), 15-26.

Ko, S., \& Butler, J. E. Need for Cognition, Alertness and Entrepreneurial Opportunity Identification. In Academy of Management Meeting, Philadelphia, USA, August 3-9 2007: Academy of Management

Krueger, N. F. J., \& Dickson, P. R. (1994). How believing in ourselves increases risk taking: Perceived self-efficacy and opportunity recognition. Decision Sciences, 25(3), 385400.

Livingston, C., \& Borko, H. (1989). Expert-novice differences in teaching: a cognitive analysis and implications for teacher education. Journal of Teacher Education, 40(4), $36-42$.

McGee, J., Peterson, M., Mueller, S., \& Sequeira, J. (2009). Entrepreneurial self efficacy: refining the measure. Entrepreneurship: Theory and Practice, 33(4), 965-988.

Mitchell, J. R., \& Shepherd, D. A. (2010). To thine own self be true: images of self, images of opportunity, and entrepreneurial action. Journal of Business Venturing, 25(1), 138154.

Orland-Barak, L., \& Yinon, H. (2005). Sometimes a novice and sometimes an expert: mentors' professional expertise as revealed through their stories of critical incidents. Oxford Review of Education, 31(4), 557-578. 
Orwa, B. O. (2003). An examination of factors influencing entrepreneurial opportunity identification process. Doctoral thesis, Illinois University, Urbana Champaing, Illinois, U.S.A.

Ozgen, E. (2003). Entrepreneurial opportunity recognition: information flow, social and cognitive perspectives. Unpublished doctoral dissertation, Rensselaer Polytechnic Institute, Troy, NY.

Ozgen, E., \& Baron, R. A. (2007). Social sources of information in opportunity recognition: Effects of mentors, industry networks, and professional forums. Journal of business venturing, 22(2), 174-192.

Politis, D. (2005). The Process of Entrepreneurial Learning: A Conceptual Framework. Entrepreneurship Theory and Practice, 29(4), 399-424.

Powers, L. E., Sowers, J.-A., \& Stevens, T. (1995). An exploratory, randomized study of the impact of mentoring on the self-efficacy and community-based knowledge of adolescents with severe physical challenges. The Journal of Rehabilitation, 61(1), 3342.

Puhakka, V. (2006). Effects of social capital on the opportunity recognition process. Journal of Enterprising Culture, 14(2), 105-124.

Radu Lefebvre, M., \& Redien-Collot, R. (2013). BHow to do things with words`: the discursive dimension of experiential learning in entrepreneurial mentoring Dyads. Journal of Small Business Management, 51(3), 370-393.

Rigg, C., \& O'Dwyer, B. (2012). Becoming an entrepreneur: researching the role of mentors in identity construction. Education + Training, 54(4), 319-329.

Sarri, K., \& Petridou, E (2006). Mentoring support for start-up female entrepreneurs-The Greek situation. In Internationalizing Entrepreneurship Education and Training Conference, Sao Paulo, Brazil, July, 9-12.

Schlaegel, C., \& Koenig, M. (2014). Determinants of entrepreneurial intent: a meta-analytic test and integration of competing models. Entrepreneurship: Theory and Practice, $38(2), 291-332$.

Shane, S. (2000). Prior knowledge and the discovery of entrepreneurial opportunities. Organization Science, 11(4), 448-469.

Shane, S. (2003). A general theory of entrepreneurship: The individual-opportunity nexus. Massachusetts, USA: Edward Elgar Pub.

Shane, S., \& Venkataraman, S. (2000). The promise of entrepreneurship as a field of research. [Note]. Academy of management review, 25(1), 217-226.

Shepherd, D., \& DeTienne, D. (2005). Prior knowledge, potential financial reward, and opportunity identification. Entrepreneurship Theory and Practice, 29(1), 91-112.

Shepherd, D. A., \& DeTienne, D. R. Discovery of opportunities: Anomalies, accumulation and alertness. In Frontiers of entrepreneurship research, Babson College, Wellesley, MA, 2001

Shinnar, R. S., Giacomin, O., \& Janssen, F. (2012). Entrepreneurial perceptions and intentions: the role of gender and culture. Entrepreneurship: Theory and Practice, 36(3), 465-493.

Short, J. C., Ketchen, D. J., Shook, C. L., \& Ireland, R. D. (2010). The concept of "opportunity" in entrepreneurship research: Past accomplishments and future challenges. Journal of Management, 36(1), 40-65.

Singh, R. P. (2000). Entrepreneurial Opportunity Recognition Through Social Networks. New York: Garland Publishing Inc.

Singh, R. P., Hills, G. E., Hybels, R. C., \& Lumpkin, G. T. Opportunity recognition through social network characteristics of entrepreneurs. In Frontiers of entrepreneurship research, Babson, MA, 1999: Babson College 
Smith, B., Matthews, C., \& Schenkel, M. (2009). Differences in Entrepreneurial Opportunities: The Role of Tacitness and Codification in Opportunity Identification. Journal of Small Business Management, 47(1), 38-57.

Stanulis, R. N., \& Jeffers, L. (1995). Action research as a way of learning about teaching in a mentor/student teacher relationship. Action in Teacher Education, 16(4), 14-24.

St-Jean, E. (2011). Mentor functions for novice entrepreneurs. Academy of Entrepreneurship Journal, 17(1), 65-84.

St-Jean, E. (2012). Mentoring as professional development for novice entrepreneurs: maximizing the learning. International Journal of Training and Development, 16(3), 200-216. doi:10.1111/j.1468-2419.2012.00404.x.

St-Jean, E., \& Audet, J. (2012). The Role of Mentoring in the Learning Development of the Novice Entrepreneur. International Entrepreneurship and Management Journal, 8(1), 119-140.

St-Jean, E., Nafa, A., Tremblay, M., Janssen, F., Baronet, J., \& Loué, C. (2014). Entrepreneurial intentions of university students: an international comparison between African, European and Canadian students. International Journal of Entrepreneurship and Innovation Management, 18(2/3), 95-114.

Sullivan, R. (2000). Entrepreneurial learning and mentoring. International Journal of Entrepreneurial Behaviour \& Research, 6(3), 160-175.

Thompson, E. (2009). Individual entrepreneurial intent: construct clarification and development of an internationally reliable metric. Entrepreneurship: Theory and Practice, 33(3), 669-694.

Tumasjan, A., \& Braun, R. (2012). In the eye of the beholder: how regulatory focus and selfefficacy interact in influencing opportunity recognition. Journal of Business Venturing, 27(6), 622-636. doi:10.1016/j.jbusvent.2011.08.001.

Ucbasaran, D., Westhead, P., \& Wright, M. (2008). Opportunity identification and pursuit: does an entrepreneur's human capital matter? Small Business Economics, 30(2), 153173.

Ucbasaran, D., Westhead, P., \& Wright, M. (2009). The extent and nature of opportunity identification by experienced entrepreneurs. Journal of business venturing, 24(2), 99115 .

Vaghely, I. P., \& Julien, P.-A. (2010). Are opportunities recognized or constructed?: An information perspective on entrepreneurial opportunity identification. Journal of business venturing, 25(1), 73-86.

Viator, R. E. (1999). An analysis of formal mentoring programs and perceived barriers to obtaining a mentor at large public accounting firms. Accounting Horizons, 13(1), 3753.

Wanberg, C. R., Welsh, E. T., \& Hezlett, S. A. (2003). Mentoring Research: A Review and Dynamic Process Model. In J. J. Martocchio, \& G. R. Ferris (Eds.), Research in Personnel and Human Resources Management (Vol. 22, pp. 39-124, Vol. 1). Oxford, U.K.: Elsevier Science Ltd.

Welpe, I. M., Spörrle, M., Grichnik, D., Michl, T., \& Audretsch, D. B. (2012). Emotions and opportunities: the interplay of opportunity evaluation, fear, joy, and anger as antecedent of entrepreneurial exploitation. Entrepreneurship: Theory and Practice, 36(1), 69-96.

Westerman, D. A. (1991). Expert and novice teacher decision making. Journal of Teacher Education, 42(4), 292-305.

Whyte, G., Saks, A. M., \& Hook, S. (1997). When success breeds failure: the role of selfefficacy in escalating commitment to a losing course of action. Journal of Organizational Behavior, 18(5), 415-432. 
